\title{
Decomposition and Nutrient Release Dynamics of Ficus benghalensis L. Litter in Traditional Agroforestry Systems of Karnataka, Southern India
}

\author{
B. Dhanya, ${ }^{1,2}$ Syam Viswanath, ${ }^{1}$ and Seema Purushothaman ${ }^{3}$ \\ ${ }^{1}$ Tree Improvement and Propagation Division, Institute of Wood Science and Technology, Malleswaram, Bangalore, \\ Karnataka 560003, India \\ ${ }^{2}$ Department of Environmental Science, College of Agriculture, University of Agricultural Sciences, PB No. 329, Raichur, \\ Karnataka 584102, India \\ ${ }^{3}$ Azim Premji University, Bangalore, Karnataka 560100, India
}

Correspondence should be addressed to B. Dhanya; krupaias@gmail.com

Received 19 November 2012; Accepted 27 January 2013

Academic Editors: P. Robakowski and S. F. Shamoun

Copyright (C) 2013 B. Dhanya et al. This is an open access article distributed under the Creative Commons Attribution License, which permits unrestricted use, distribution, and reproduction in any medium, provided the original work is properly cited.

Decomposition and nutrient release dynamics of leaf litter of Ficus benghalensis, a common agroforestry species in southern dry agroclimatic zone of Karnataka, were studied using the standard litter bag technique in surface and subsurface methods of application. Results revealed a marginally higher rate of decay in subsurface placement $22.5 \%$ of initial litter mass remaining after one year of decomposition) compared to surface treatment ( $28.3 \%$ of initial litter mass remaining). Litter quality (lignin content and lignin/N ratio) and climatic and soil conditions of the study site (monthly rainfall and soil moisture) were found to influence the rate of decomposition. Mineralisation of litter was found to be in the order $\mathrm{K}>\mathrm{N}>\mathrm{P}$. The paper further discusses the implications of these results for rainfed farming in Mandya and emphasises the potential of $F$. benghalensis in reducing nutrient input costs for resource-poor dryland farmers.

\section{Introduction}

Agroforestry systems with scattered trees in croplands have traditionally played a pivotal role in sustaining rural livelihoods in semiarid zones of the world. In Mandya district of southern dry agroclimatic zone of Karnataka, trees of the genus Ficus have been integral components of traditional rainfed agroecosystems with field crops like millets, pulses, maize and oil seeds. Ficus benghalensis L. is the major species of Ficus grown in these agroforestry systems, followed by Ficus religiosa L., Ficus amplissima Sm., Ficus virens Aiton, Ficus racemosa L., and Ficus mysorensis var. pubescens (Roth). [1]. In preliminary surveys held in Mandya, farmers were appreciative of the various direct benefits (fodder, firewood, small timber, and shade) and ecological services from these trees, especially soil enrichment through litterfall. Farmer interviews also revealed that litter from Ficus trees helped to reduce compost usage by 3 tonnes per hectare. However, scientific studies on the value of Ficus trees as source of litter nutrients in agroforestry systems of semiarid tropics are lacking. The relative value of litter as a source of nutrient is dependent on its decomposition rate, which in turn controls the release of the tissue-held mineral ions [2]. Further, the process of decomposition is regulated by a host of variables including physical and chemical properties (quality) of litter, climate, soil properties, and decomposer communities consisting of microorganisms and soil invertebrates $[3,4]$. In the present study, leaf litter decomposition of Ficus benghalensis, factors influencing decomposition process, and pattern of nutrient release were assessed with the objective of eliciting information that may help resource-poor farmers to optimally exploit Ficus litterfall to reduce input costs for farming. 


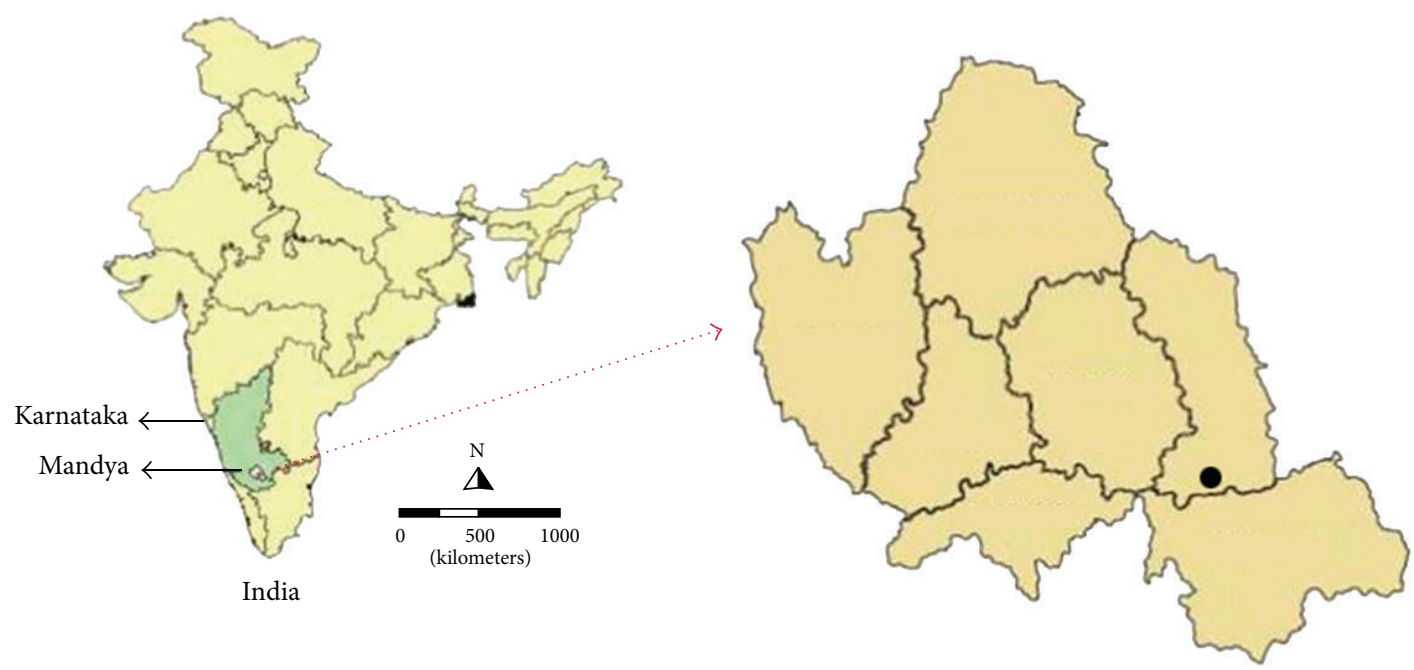

FIGURE 1: Location map of Mandya district in Karnataka state (black dot indicates the experimental site).

It is hypothesised that if utilized properly, Ficus litterfall can substantially contribute to nutrient needs of dryland farming in Mandya.

\section{Materials and Methods}

2.1. Study Area. Mandya district, spanning an area of $4961 \mathrm{~km}^{3}$ in southern dry agroclimatic zone of Karnataka state in south India (location map in Figure 1), consists of plain lands, with an elevation of $757 \mathrm{~m}-909 \mathrm{~m}$ above mean sea level. A plot of area 0.8 ha, located at $12^{\circ} 29^{\prime} \mathrm{N}$ latitude and $76^{\circ} 59^{\prime}$ E longitude, was selected for litter decomposition studies in Mandya, where F. benghalensis trees were grown in association with (Eleusine coracana (L.) Gaertn.) and horse gram (Macrotyloma uniflorum (Lam.) Verdc.). The mean daily minimum and maximum temperatures for 2009 were $19^{\circ} \mathrm{C}$ and $31.5^{\circ} \mathrm{C}$, respectively, and total annual rainfall for the year was $800 \mathrm{~mm}$, with most of the rain received during the premonsoon month of May and monsoon months of June-September. Soil in the study site was red and slightly acidic ( $\mathrm{pH}$ of 6.5), and the texture ranged from gravelly sandy clay to sandy clay loam. Organic carbon content of soil was $1.33 \%$, available $\mathrm{N}$ content was $204.3 \mathrm{~kg} / \mathrm{ha}$, available $\mathrm{P}$ was $2.5 \mathrm{~kg} / \mathrm{ha}$, and available $\mathrm{K}$ was $642.2 \mathrm{~kg} / \mathrm{ha}$. Exchangeable Ca and $\mathrm{Mg}$ were high at $2102.1 \mathrm{ppm}$ and $420.4 \mathrm{ppm}$, respectively, and available $S$ had a moderate value of $47.9 \mathrm{ppm}$.

2.2. Litter Decomposition Studies. In the present investigation, only leaf litter was studied for decomposition as this component constituted around $60 \%$ of the total litterfall of $F$. benghalensis in agroforestry systems of Mandya [5]. The standard litterbag technique [6] was employed for decomposition studies, in which nylon bags of size $30 \mathrm{~cm} \times 20 \mathrm{~cm}$ and mesh size $2 \mathrm{~mm}$ were filled with $20 \mathrm{~g}$ of freshly fallen/senescent foliage of $F$. benghalensis, shade dried for 48 hours. Filter paper chopped into small pieces was also transferred to similar bags as control, to determine the importance of chemical constitution in influencing decomposition [7]. A total of 60 litter bags and 60 filter paper bags (total of 120 bags) were buried just below the soil surface (subsurface treatment) to simulate the litter that goes inside soil when land is ploughed. An equal number of litter bags and filter paper bags were placed on surface of soil (surface treatment) to study the effect of method of placement on decomposition. Thus, a total of 240 such bags (two substrates for 12 months and two methods of application) were laid out for decomposition experiments under Ficus tree canopy in substrate-wise strips to facilitate easy retrieval of bags per sampling date. Samples of air-dried litter were also kept apart for analysis of N (microKjeldahl method in Kel Plus-KES 6L Automatic Distillation Unit), P (vanadomolybdophosphoric yellow colour method) $\mathrm{K}$ (flame photometry using Elico-CL 378 flame photometer) [8], C [9], lignin (Klason's procedure [10]), and total phenol content (Folin-Ciocalteau reagent method [11]).

Five samples each were drawn at monthly intervals from surface and subsurface treatments for one year starting from April 2009 to March 2010. The residual substrate (litter/paper) mass from bags was washed, oven-dried at $70^{\circ} \mathrm{C}$, and weighed after excluding fine roots and macroarthropods penetrating the mesh. The samples were then pooled substrate-wise, powdered, and analysed for $\mathrm{N}, \mathrm{P}$ and $\mathrm{K}$. Decomposition rates of the substrates were estimated from the first-order exponential equation

$$
e^{-k t}=\frac{L_{R}}{L_{I}},
$$

where $k=$ decomposition rate per year, $t=$ the time interval of sampling $L_{R}$ expressed in years, $L_{R}=$ the litter weight remaining at a given time, and $L_{I}=$ initial litter weight at time zero [15].

Half-life period $\left(t_{0.5}\right)$ of the decomposing litter samples was estimated from $k$ values using the equation

$$
t_{0.5}=\frac{0.693}{-k}
$$


Nutrient content of the decomposing leaf was derived as

$$
\% \text { nutrient remaining }=\left(\frac{C}{C_{0}}\right)\left(\frac{\mathrm{DM}}{\mathrm{DM}_{0}}\right) \times 10^{2},
$$

where $C$ is the concentration of element in the leaf litter at the time of sampling, $C_{0}$ is the concentration of the initial leaf litter kept for decomposition, DM is the dry matter at the time of sampling, and $\mathrm{DM}_{0}$ is the initial dry matter of the litter sample kept for decomposition [16].

$\%$ nutrient released

$$
=100-\% \text { of original nutrient remaining; }
$$

see $[17]$.

2.3. Factors Influencing Litter Decomposition. The association of litter decomposition with litter quality, climatic conditions, and soil properties was examined in the present study.

2.3.1. Litter Quality. Litter quality determines in part rates of decomposition and release of nutrients from organic residues [18]. Initial concentrations of N, lignin (LG), and polyphenol $(\mathrm{PP}$ ) and ratios such as $\mathrm{C}: \mathrm{N}, \mathrm{LG}: \mathrm{N}$, and $\mathrm{PP}: \mathrm{N}$ in the biomass are some of the factors that have been shown to influence decomposition rates $[19,20]$. In the present study litter quality parameters in terms of contents of nitrogen, lignin, and polyphenol and $\mathrm{C}: \mathrm{N}$ and $\mathrm{LG}: \mathrm{N}$ ratios were analysed following Jama and Nair [7] and Niranjana [21].

2.3.2. Collection of Weather Data. Monthly rainfall data recorded from the rain gauge at Bharathi Nagara, located $1.5 \mathrm{~km}$ from the study site, was collected from the District Statistics Office, Mandya. Air temperature and humidity were measured in situ using thermohygrometer (Temp Tec brand, Mextech Company, Maharashtra, India) once monthly from April 2009 to March 2010.

2.3.3. Analysis of Soil Properties. Soil temperature was measured in situ using a soil thermometer (Universal brand, Universal Soil Equippers, New Delhi, India). Samples from the site were carried to laboratory once in a month from April 2009 to March 2010 for gravimetrical estimation of soil moisture and measurement of soil $\mathrm{pH}$.

2.4. Statistical Analyses. Data on residual litter mass in bags and their nutrient contents after one year for surface and subsurface methods of placement were statistically analysed using two-way ANOVA technique (substrate and method of placement as two factors) in SigmaStat 3.5 statistical software, and Fisher's least square difference (LSD) values were computed. Pearson's correlation coefficients of mean monthly weight loss of litter with weather parameters and soil properties in the experimental plot were worked out following Panse and Sukhatme [22].

\section{Results and Discussion}

3.1. Pattern of Litter Decay. Previous studies have shown that litter decay can follow an exponential pattern $[23,24]$ or a

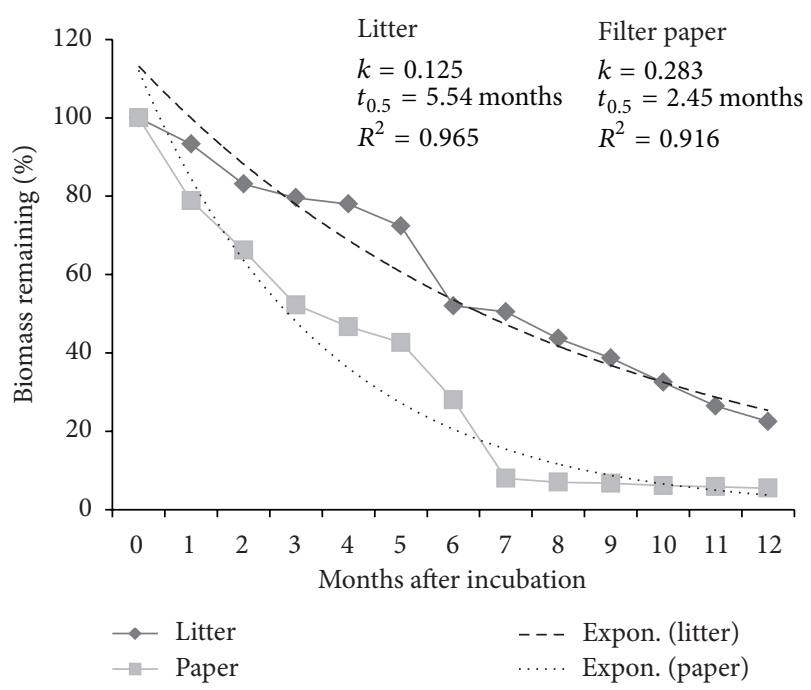

FIGURE 2: Weight loss of $F$. benghalensis litter and filter paper substrates in subsurface method of application in agroforestry systems of Mandya (Expon. denotes the exponential trendline fitted).

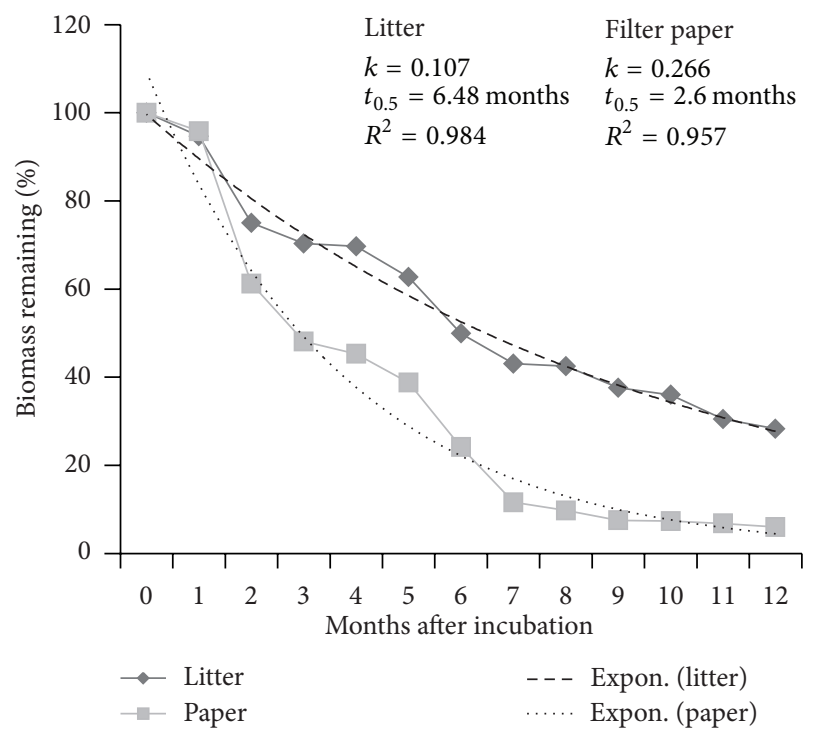

FIgURE 3: Weight loss of $F$. benghalensis litter and filter paper substrates in surface method of application in agroforestry systems of Mandya (Expon. denotes the exponential trendline fitted).

linear pattern $[2,14,21]$ depending upon the species studied and conditions (climate, soil, method of application, etc.) under which decomposition takes place. In the case of $F$. benghalensis leaf litter decomposition in Mandya, a biphasic mode of decay was apparent with an initial rapid phase of mass loss in first 6-7 months, followed by a later slower phase from 8 to 12 months. Hence, a negative exponential model $\left(Y_{t}=Y_{0} e^{-k x}\right.$, where $Y_{0}$ is the initial litter mass applied and $Y_{t}$ is the dry matter remaining after $x$ months) was used to describe the weight loss pattern of litter and filter paper substrates during decomposition (Figures 2 and 3 ). 
TABLE 1: Litter quality parameters of $F$. benghalensis in comparison with other substrates.

\begin{tabular}{|c|c|c|c|c|c|c|c|c|}
\hline Species/substrate & Location & $\begin{array}{c}\text { Initial } \mathrm{N} \\
(\%)\end{array}$ & $\begin{array}{c}\text { Initial } \\
\text { lignin (\%) }\end{array}$ & $\begin{array}{l}\text { Initial total } \\
\text { phenol (\%) }\end{array}$ & $\mathrm{C} / \mathrm{N}$ ratio & $\begin{array}{l}\text { Lignin/N } \\
\text { ratio }\end{array}$ & Half life (in months) & Reference \\
\hline F. benghalensis & Mandya & 1.11 & 30.50 & 6.76 & 23.89 & 27.60 & $5.54-6.47$ & Primary data \\
\hline Filter paper & Mandya & 0.04 & 0.50 & 0.47 & 70.49 & 12.19 & $2.45-2.60$ & Primary data \\
\hline F. glomerata & Garhwal, India & 1.97 & 13.82 & 7.10 & 19.88 & 7.01 & 8.00 & {$[12]$} \\
\hline F. roxburghii & Garhwal, India & 0.96 & 12.14 & 11.64 & 39.58 & 12.64 & 12.00 & {$[12]$} \\
\hline \multirow{2}{*}{ Artocarpus hirsutus } & Kerala, India & 1.10 & 28.90 & 2.20 & $\ldots$ & 26.20 & 4.60 & {$[13]$} \\
\hline & Kerala, India & 1.73 & 31.40 & $\ldots$ & $\cdots$ & 18.16 & 3.40 & {$[14]$} \\
\hline \multirow[t]{2}{*}{ A. heterophyllus } & Kerala, India & 0.91 & 15.20 & 2.00 & $\cdots$ & 17.60 & 2.40 & {$[13]$} \\
\hline & Kerala, India & 2.15 & 17.90 & $\ldots$ & $\cdots$ & 8.33 & 3.10 & {$[14]$} \\
\hline
\end{tabular}

$\cdots$ : data not available.

Decomposition was found to be faster in subsurface method of application, with only $22.5 \%$ of initial litter mass remaining after one year of incubation, while in surface treatment, $28.3 \%$ of mass was remaining. Decay constant of litter was slightly higher for subsurface mode of application (0.125) compared to surface mode (0.107), and half-life of litter ranged from 5.54 months in subsurface treatment to 6.48 months in surface treatment indicating a modestly faster decay in subsurface treatment. But this difference in decay rate between treatments did not appear significant in twoway ANOVA $(F=0.0187 ; P=0.892)$, probably due to the failure of placement directly below soil surface to bring litter in more contact with decomposers. Hence, for faster decomposition, deeper placement inside soil may be required which implies that in-field Ficus litter has to be ploughed deeply or composted separately for faster decomposition and quicker release of nutrients.

Two-way ANOVA results also revealed that between substrates, there is a significant variation in decomposition $(F=11.640$; LSD for comparison of substrates = 2.937; $P<0.001)$. The control filter paper substrate, decomposed faster and had only $5.5 \%-6 \%$ of mass remaining after one year. Filter paper also had a biphasic pattern of mass decline similar to results from semiarid regions of Kenya [7]. ANOVA did not show significant differences for treatment $\times$ substrate interaction.

Decay constant of $F$. benghalensis litter as determined in the present study is lower than many tropical tree species [14], while decomposition was faster compared to F. glomerata and F. roxburghii studied in central Himalayas [12] (Table 1).

\subsection{Factors Influencing Litter Decay}

3.2.1. Litter Quality. Differences in decomposition rates can probably be explained by variations in litter quality [25] and in climatic and soil conditions of study sites [15]. Litters with low lignin and phenolics and higher nitrogen content are generally considered good quality material for decomposition [26]. F. benghalensis litter has medium $\mathrm{N}$ content (as per the classification of Jamaludheen and Kumar [14]) and high lignin and polyphenol contents (Table 1), making it a poor quality litter.
Comparison of litter quality of $F$. benghalensis with similar species (of the same genus or family) suggests that high lignin content and lignin/ $\mathrm{N}$ ratio are the main attributes responsible for its slow decomposition and longer half life period compared to other species. Tian et al. [20] and Constantinides and Fownes [27] argued that initial N content of litter is the best predictor of decomposition and has a positive influence. Litter with high $\mathrm{N}$ content in relation to $\mathrm{C}$ (low $\mathrm{C}: \mathrm{N}$ ratio) is known to mineralize faster. But filter paper with highest $\mathrm{C}: \mathrm{N}$ ratio had rates of decomposition higher than litter, which suggests that in absence of lignin, wide $\mathrm{C}: \mathrm{N}$ ratio per se may not be a limiting factor [7]. Lignin is highly resistant to enzymatic attack and physically interferes with decay of other chemical fractions in leaf tissue hence, slows down decomposition process. But absolute lignin concentration is not of much use as its concentration in relation to $\mathrm{N}$, in predicting decay rates of litter [12]. By virtue of its high lignin content, F. benghalensis has the highest lignin : $\mathrm{N}$ ratio of all species compared in Table 1 which may explain the persistence of the litter. Artocarpus hirsutus litter had higher lignin content (as reported by Isaac and Nair [13]); yet, decomposition was faster due to higher $\mathrm{N}$ content and lower lignin/ $\mathrm{N}$ ratio and also due to favourable in situ climatic conditions. Similarly, F. roxburghii with lower lignin and higher $\mathrm{N}$ contents than $F$. benghalensis had longer halflife due to the cooler environmental conditions of the study area.

3.2.2. Climatic and Soil Conditions of Study Site. Association between $F$. benghalensis litter decay and climatic and soil parameters was investigated (Table 2). As there was no significant difference in decomposition between surface and subsurface applications of litter, mean of monthly weight loss of litter in surface and subsurface treatments was correlated to various climatic parameters (temperature, humidity, and rainfall) and soil properties (moisture, temperature, and $\mathrm{pH}$ ). Weight loss was found to be significantly and positively correlated to monthly rainfall (Pearson's correlation coefficient $=$ 0.736; $P<0.01$ ) and soil moisture (Pearson's correlation coefficient $=0.608 ; P<0.05)$. This implies that litter decomposition and subsequent nutrient release are higher in high rainfall months when soil moisture is also high. Association 
TABLE 2: Correlations of litter weight loss with climatic and soil parameters of study site.

\begin{tabular}{|c|c|c|c|c|c|c|c|}
\hline Parameter & Mean monthly weight loss & Soil temperature & Soil moisture & Air temperature & Relative humidity & Rainfall & Soil pH \\
\hline Mean monthly weight loss & $\begin{array}{ll}s & 1\end{array}$ & -0.39 & $0.608^{*}$ & -0.077 & -0.197 & $0.736^{* *}$ & -0.234 \\
\hline Soil temperature & & 1 & $-0.735^{* *}$ & $0.719^{* *}$ & $-0.762^{* *}$ & $-0.681^{*}$ & -0.311 \\
\hline Soil moisture & & & 1 & -0.234 & 0.416 & $0.703^{*}$ & 0.268 \\
\hline Air temperature & & & & 1 & $-0.628^{*}$ & -0.139 & -0.446 \\
\hline Relative humidity & & & & & 1 & 0.19 & 0.338 \\
\hline Rainfall & & & & & & 1 & -0.096 \\
\hline Soil pH & & & & & & & 1 \\
\hline
\end{tabular}

* Significant at $P<0.05 ;{ }^{* *} P<0.01$.

TABLE 3: Concentrations of major nutrients in F. benghalensis leaf litter retrieved at monthly intervals on decomposition.

\begin{tabular}{|c|c|c|c|c|c|c|}
\hline \multirow{2}{*}{ Month after incubation } & \multicolumn{2}{|c|}{$\mathrm{N}(\%)$} & \multicolumn{2}{|c|}{$\mathrm{P}(\%)$} & \multicolumn{2}{|c|}{$\mathrm{K}(\%)$} \\
\hline & Surface & Subsurface & Surface & Subsurface & Surface & Subsurface \\
\hline 0 (initial) & \multicolumn{2}{|c|}{1.105} & \multicolumn{2}{|c|}{0.0845} & \multicolumn{2}{|c|}{1.004} \\
\hline 1 & 0.903 & 1.089 & 0.152 & 0.220 & 0.681 & 0.183 \\
\hline 2 & 0.967 & 1.050 & 0.129 & 0.096 & 0.994 & 0.080 \\
\hline 3 & 0.940 & 1.050 & 0.291 & 0.230 & 0.357 & 0.191 \\
\hline 4 & 0.992 & 1.005 & 0.486 & 0.211 & 0.206 & 0.175 \\
\hline 5 & 0.947 & 1.030 & 0.172 & 0.119 & 0.199 & 0.099 \\
\hline 6 & 0.740 & 1.080 & 0.273 & 0.197 & 0.199 & 0.164 \\
\hline 7 & 1.340 & 0.660 & 0.066 & 0.075 & 0.384 & 0.062 \\
\hline 8 & 1.230 & 0.974 & 0.171 & 0.070 & 0.284 & 0.058 \\
\hline 9 & 1.470 & 1.250 & 0.343 & 0.077 & 0.374 & 0.064 \\
\hline 10 & 1.410 & 1.190 & 0.420 & 0.103 & 0.325 & 0.085 \\
\hline 11 & 1.297 & 1.240 & 0.129 & 0.115 & 0.261 & 0.091 \\
\hline 12 & 1.320 & 1.023 & 0.166 & 0.110 & 0.410 & 0.110 \\
\hline LSD (0.05) & $\mathrm{T}: \mathrm{NS}$ & $\mathrm{P}: \mathrm{NS}$ & $\mathrm{T}: 0.0774^{*}$ & $\mathrm{P}: \mathrm{NS}$ & $\mathrm{T}: 0.153^{* *}$ & $\mathrm{P}: \mathrm{NS}$ \\
\hline
\end{tabular}

T: treatment; P: period; NS: not significant. ${ }^{*}$ Significant at $P<0.05 ;{ }^{* *} P<0.01$.

between rainfall and litter weight loss has been documented by Upadhyay and Singh [4] and Mugendi and Nair [15]. Jamaludheen and Kumar [14] documented a positive, yet nonsignificant, relation of soil moisture with residual litter weight. Soil $\mathrm{pH}$ had no significant effect on litter decay in the present study, which corroborates observations of Mugendi and Nair [15]. Soil temperature is highly negatively correlated to soil moisture (Pearson's correlation coefficient $=0.735$; $P<0.01)$ and, hence, may have an indirect impact on litter decomposition due to its influence on soil moisture. Role of soil factors in litter decomposition is generally underplayed in comparison to climatic factors or litter quality $[15,28]$. But results of the present study indicate that in addition to litter quality and climate, soil properties may also significantly influence litter decomposition.

3.3. Nutrient Dynamics in Litter Decay. Analysis of elemental composition of decomposing litter revealed an initial rapid loss of $\mathrm{N}$ for the first six-seven months, followed by an increase in the concentration in subsequent months (Table 3 ). The initial decline might be due to the leaching of soluble forms of nitrogen. Second phase of increase may be attributed to immobilization of $\mathrm{N}$ by microbial population infesting the litter. Similar pattern of $\mathrm{N}$ release was recorded from litters of
Ailanthus triphysa and Swietenia macrophylla [13]. P concentrations showed an increasing trend owing to retention of the element in microbial tissues. Similar results were reported for $P$ release by 13,29 , and 18 . Potassium concentrations showed a rapid decline. Being a nonstructural element, $\mathrm{K}$ is highly mobile and is easily lost by leaching $[29,30]$.

When the percentage of nutrients remaining after one year of decomposition was computed from residual nutrient concentrations and litter mass, it was found that proportion of residual nutrients was less in subsurface treatment compared to surface treatment, indicating comparatively faster nutrient release when the litter is incorporated to the soil. After one year of decomposition, $33.80 \%$ of initial $\mathrm{N}$ content was remaining in surface treatment, while in subsurface treatment only $20.83 \%$ was remaining. However, two-way ANOVA of nutrient release showed that there was no significant difference in release of $\mathrm{N}$ between surface and subsurface treatments $(F=0.933 ; P=0.355)$. But release of $\mathrm{P}(F=$ 7.724; LSD for comparing treatments $=0.0774 ; P<0.05)$ and $\mathrm{K}(F=15.781 ; \mathrm{LSD}=0.153 ; P<0.01)$ varied significantly between treatments. Mineralisation was fastest for $\mathrm{K}$ due to its highly mobile nature and susceptibility to leaching, while $\mathrm{P}$ was the most persistent nutrient. After one year of decomposition, $2.45 \%$ of $\mathrm{K}$ was remaining in subsurface 
treatment and $11.55 \%$ in surface treatment, while $29.29 \%$ and $55.71 \%$ of $\mathrm{P}$ was remaining in surface and subsurface treatments, respectively. Order of mineralization followed the pattern $\mathrm{K}>\mathrm{N}>\mathrm{P}$ in both surface and subsurface treatments. However, general trend in nutrient release showed that processes determining $\mathrm{P}$ and $\mathrm{K}$ release may not be correlated with $\mathrm{N}$ release [12]. Effect of months was not significant for all the elements.

\section{Conclusions}

The pattern of litter decomposition and nutrient release has important implications for exploiting F. benghalensis as an agroforestry species in Mandya. Litter quality and the timing of litterfall determine the contribution of leaf litter of agroforestry trees to soil fertility through decomposition [12]. In the case of Ficus, two phases of heavy litterfall occur: first during October-November and then during January-February [5]. Decomposition studies indicate that litter decomposes to half of its original mass only in six months of decay. Thus the slow release of nutrients from surge of litterfall in October-November facilitates summer cropping in April, while the second peak in February makes nutrients available for monsoon cropping in July. Higher litter weight loss during the rainy season enhances nutrient availability for monsoon crops. Results of the study also point to the need of ploughing the litter inside soil or separate composting if nutrient release is to be accelerated, while slow rate of decomposition on soil surface indicates the potential of the litter to be used as an organic mulch to conserve moisture of agricultural soils in semiarid areas. For proper utilisation of Ficus litter, it is also important to clearly understand its allelopathic potential, as inhibitory effects of Ficus benghalensis bark and leaf extracts on weeds, microbes, and crops are widely reported in the literature [31-34]. However, Ficus agroforestry in Mandya is a time-tested practice, and hence, negative interactions of trees with common crops in these systems may be minimal. Litter decomposition and nutrient release pattern of Ficus trees potentially complement the cropping pattern in rainfed farmlands of Mandya and augment nutrient availability to crops, thereby affecting considerable saving on external nutrient input costs in dryland farming and contributing to the overall sustainability of the system.

\section{Acknowledgments}

The authors wish to acknowledge the University Grants Commission, New Delhi, and Indian Council of Forestry Research and Education, Dehradun, for financial assistance and Director, Institute of Wood Science and Technology, Bangalore, for logistic support. Mr. K. M. Shivaswamy, Karadakere village, Mandya, is sincerely thanked for providing space in his farmland for litter decomposition experiment, and reviewers are thanked for critical suggestions.

\section{References}

[1] B. Dhanya, S. Viswanath, S. Purushothaman, and B. Suneeta, "Ficus trees as components of rainfed agrarian systems in
Mandya district of Karnataka," My Forest, vol. 46, no. 2, pp. 161$165,2010$.

[2] S. R. Isaac and M. A. Nair, "Decomposition of wild jack (Artocarpus hirsutus Lamk.) leaf litter under sub canopy and open conditions," Journal of Tropical Agriculture, vol. 42, no. 1-2, pp. 29-32, 2004.

[3] V. Meentemeyer and B. Berg, "Regional variation in rate of mass loss of Pinous sylvestris needle litter in Swedish pine forest as influenced by climate and litter quality," Canadian Journal of Forest Research, vol. 1, pp. 167-180, 1986.

[4] V. P. Upadhyay and J. S. Singh, "Patterns of nutrient immobilization and release in decomposing forest litter in Central Himalaya, India," Journal of Ecology, vol. 77, no. 1, pp. 147-161, 1989.

[5] B. Dhanya, Integrated study of a Ficus based traditional agroforestry system in Mandya district, Karnataka [Ph.D. thesis], Forest Research Institute Deemed University, Dehradun, India, 2011.

[6] J. M. Anderson and J. S. Ingram, Tropical Soil Biology and Fertility: A Handbook of Methods, CAB International, Wallingford, UK, 1993.

[7] B. A. Jama and P. K. R. Nair, "Decomposition- and nitrogenmineralization patterns of Leucaena leucocephala and Cassia siamea mulch under tropical semiarid conditions in Kenya," Plant and Soil, vol. 179, no. 2, pp. 275-285, 1996.

[8] M. L. Jackson, Soil Chemical Analysis, Prentice Hall of India, New Delhi, India, 1973.

[9] A. Walkley and C. A. Black, "An examination of the Degtjareff method for determining soil organic matter and proposed modification of the chromic acid titration method," Soil Science, vol. 37, pp. 29-39, 1934.

[10] R. M. Rowell, R. Pettersen, J. S. Han, J. Rowell, and M. A. Tshabalala, "Cellwall chemistry," in Handbook of Wood Chemistry and Wood Composites, R. M. Rowell, Ed., p. 65, CRC \& Taylor \& Francis, Boca Raton, Fla, USA, 2005.

[11] S. Sadasivam and A. Manickam, Biochemical Methods For Agricultural Sciences, Wiley Eastern Limited and Coimbatore: Tamil Nadu Agricultural University, New Delhi, India, 1992.

[12] R. L. Semwal, R. K. Maikhuri, K. S. Rao, K. K. Sen, and K. G. Saxena, "Leaf litter decomposition and nutrient release patterns of six multipurpose tree species of central Himalaya, India," Biomass and Bioenergy, vol. 24, no. 1, pp. 3-11, 2003.

[13] S. R. Isaac and M. A. Nair, "Litter dynamics of six multipurpose trees in a homegarden in Southern Kerala, India," Agroforestry Systems, vol. 67, no. 3, pp. 203-213, 2006.

[14] V. Jamaludheen and B. M. Kumar, "Litter of multipurpose trees in Kerala, India: variations in the amount, quality, decay rates and release of nutrients," Forest Ecology and Management, vol. 115, no. 1, pp. 1-11, 1999.

[15] D. N. Mugendi and P. K. R. Nair, "Predicting the decomposition patterns of tree biomass in tropical highland microregions of Kenya," Agroforestry Systems, vol. 35, no. 2, pp. 187-201, 1997.

[16] J. G. Bockheim, E. A. Jepsen, and D. M. Heisey, "Nutrient dynamics in decomposing leaf litter of four tree species on a sandy soil in northwestern Wisconsin," Canadian Journal of Forest Research, vol. 21, no. 6, pp. 803-812, 1991.

[17] M. M. Giashuddin, D. P. Garrity, and M. L. Aragon, "Weight loss, nitrogen content changes, and nitrogen release during decomposition of legume tree leaves on and in the soil," Nitrogen Fixing Tree Research Report II, pp. 43-50, 1993. 
[18] L. T. Szott, E. C. M. Fernandes, and P. A. Sanchez, "Soil-plant interactions in agroforestry systems," Forest Ecology and Management, vol. 45, no. 1-4, pp. 127-152, 1991.

[19] C. A. Palm and P. A. Sanchez, "Nitrogen release from the leaves of some tropical legumes as affected by their lignin and polyphenolic contents," Soil Biology and Biochemistry, vol. 23, no. 1, pp. 83-88, 1991.

[20] G. Tian, B. T. Kang, and L. Brussaard, "Effects of chemical composition on $\mathrm{N}, \mathrm{Ca}$, and $\mathrm{Mg}$ release during incubation of leaves from selected agroforestry and fallow plant species," Biogeochemistry, vol. 16, no. 2, pp. 103-119, 1992.

[21] K. Niranjana, Studies on the tree-crop interactions in tea (Camellia sinensis) based shaded perennial agroforestry system in Western Ghats [Ph.D. thesis], Forest Research Institute Deemed University, Dehra Dun, India, 2006.

[22] V. G. Panse and P. V. Sukhatme, Statistical Methods For Agricultural Workers, Indian Council of Agricultural Research, New Delhi, India, 2000.

[23] M. E. Harmon, G. A. Baker, G. Spycher, and S. E. Greene, "Leaflitter decomposition in the Picea/tsuga forests of Olympic National Park, Washington, U.S.A," Forest Ecology and Management, vol. 31, no. 1-2, pp. 55-66, 1990.

[24] R. L. Edmonds and T. B. Thomas, "Decomposition and nutrient release from green needles of western hemlock and Pacific silver fir in an old-growth temperate rain forest, Olympic National Park, Washington," Canadian Journal of Forest Research, vol. 25, no. 7, pp. 1049-1057, 1995.

[25] R. H. Waring and W. H. Schlesinger, Forest Ecosystem: Concepts and Management, Academic Press, New York, NY, USA, 1985.

[26] A. Young, "Agroforestry for Soil Management," CAB International and International Centre for Research in Agroforestry, 1997.

[27] M. Constantinides and J. H. Fownes, "Nitrogen mineralization from leaves and litter of tropical plants: relationship to nitrogen, lignin and soluble polyphenol concentrations," Soil Biology and Biochemistry, vol. 26, no. 1, pp. 49-55, 1994.

[28] V. Meentemeyer, "Macroclimate and lignin control of litter decomposition rates," Ecology, vol. 59, pp. 465-472, 1978.

[29] T. J. Stohlgren, "Litter dynamics in two Sierran mixed conifer forests. II. Nutrient release in decomposing leaf litter," Canadian Journal of Forest Research, vol. 18, no. 9, pp. 1136-1144, 1988.

[30] O. P. Toky and V. Singh, "Litter synamics in short-rotation high density tree plantations in an arid region of India," Agriculture, Ecosystems and Environment, vol. 45, no. 1-2, pp. 129-145, 1993.

[31] S. Shafique, R. Bajwa, A. Javaid, and S. Shafique, "Biological control of Parthenium IV: suppressive ability of aqueous leaf extracts of some allelopathic trees against germination and early seedling growth of Parthenium hysterophorus L.," Pakistan Journal of Weed Science Research, vol. 11, no. 1-2, pp. 75-79, 2005.

[32] M. Manikandan and M. Jayakumar, "Herbicidal effect of Ficus bengalensis aqueous extract on Lpomoea pentaphylla," International Journal of Agriculture, vol. 2, no. 1, pp. 35-38, 2012.

[33] S. Shafique, A. Javaid, R. Bajwa, and S. Shafique, "Effect of aqueous leaf extracts of allelopathic trees on germination and seedborne mycoflora of wheat," Pakistan Journal of Botany, vol. 39, no. 7, pp. 2619-2624, 2007.

[34] S, Siddiqui, M. K. Meghvansi et al., "Efficacy of aqueous extracts of five arable trees on the seed germination of Pisum sativum 1 . Var-VRP-6 and KPM-522," Botany Research International, vol. 2, no. 1, pp. 30-35, 2009. 

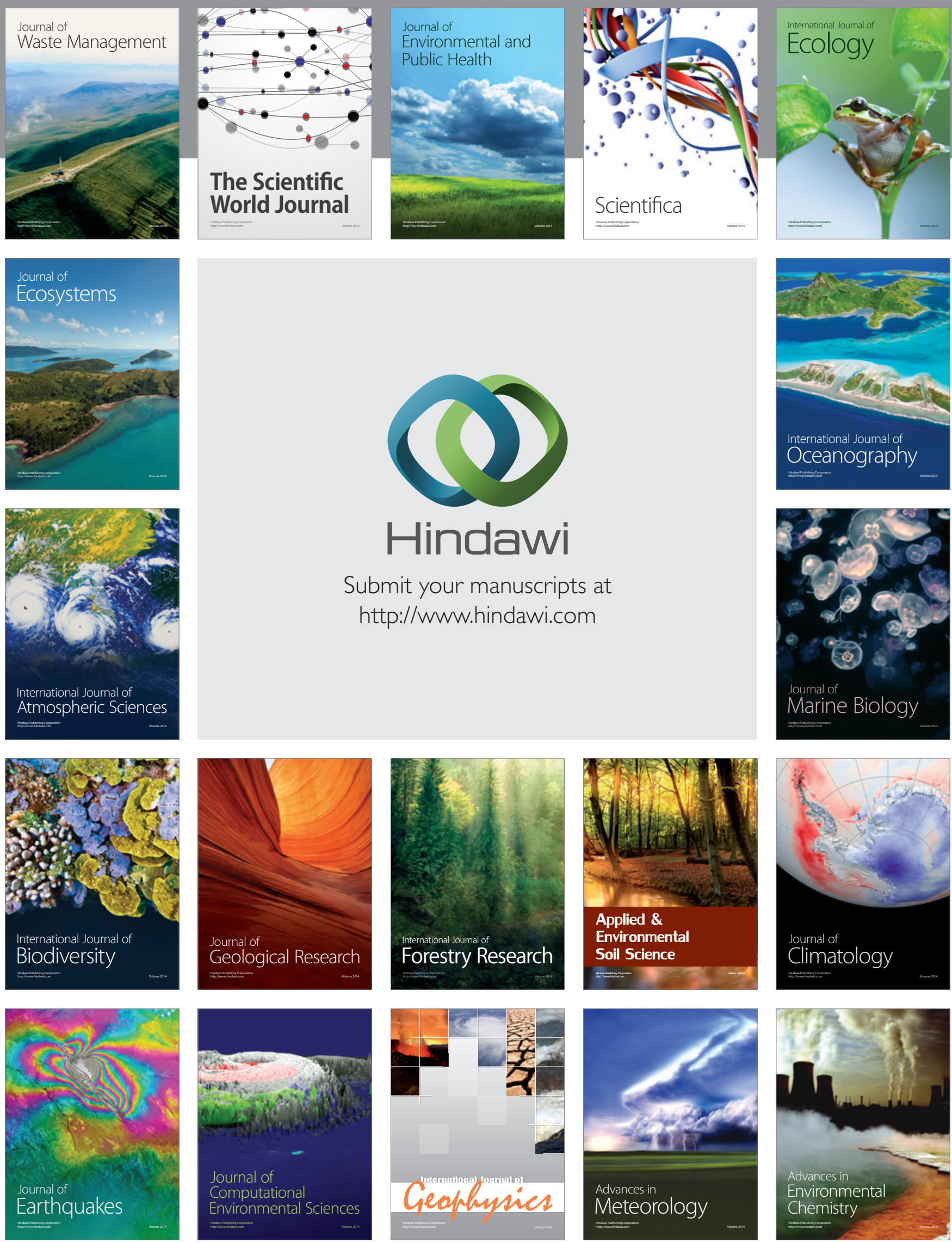